\title{
Ectopic Production of the Isolated Beta Subunit of Human Chorionic Gonadotropin
}

\author{
Bruce D. Weintraub and Saul W. Rosen \\ From the Clinical Endocrinology Branch, National Institute of Arthritis, \\ Metabolism, and Digestive Diseases, National Institutes of Health, \\ Bethesda, Maryland 20014
}

\begin{abstract}
A B S T R A C T A material similar to the beta subunit of human chorionic gonadotropin (hCG- $\beta$ ) was detected in serum $(300 \mathrm{ng} / \mathrm{ml})$ and tumor extract from a 75-yrold man with pancreatic adenosquamous carcinoma. This material was indistinguishable from hCG- $\beta$ in three different types of radioimmunoassay that displayed widely varying reactions with glycoprotein trophic hormones and their subunits. In gel chromatography there appeared to be heterogeneity of the serum betalike immunoactivity, including one component that coeluted with standard hCG- $\beta$ tracer and another immunologically indistinguishable component that displayed a slightly lower elution volume. Neither complete human chorionic gonadotropin ( $\mathrm{hCG}$ ) nor its alpha subunit was detected in radioimmunoassays of serum, before or after fractionation, or in tumor extract. The absence of complete hCG was confirmed in a gonadotropin bioassay sensitive to $15 \mathrm{ng}$ of hCG, which showed no bioactivity in serum or tumor extract containing 450 and $90 \mathrm{ng}$ of hCG- $\beta$, respectively. This case probably represents the first demonstration of isolated polypeptide subunit production of ectopic origin and suggests that ${ }^{h C G}-\beta$, as well as other subunits, may prove useful as cancer markers.
\end{abstract}

\section{INTRODUCTION}

The ectopic production of protein hormones and other polypeptides by neoplasms (1-4) is of theoretical interest and may be useful in early diagnosis of malignancy (5). Recently, attention has focused on ectopic

This work was presented in part at the 1973 Annual Meeting of the American Federation for Clinical Research, Atlantic City, N. J. (34).

Received for publication 24 May 1973 and in revised form 30 July 1973. placental proteins, including the isoenzyme placental alkaline phosphatase $(\mathrm{PAP})^{1}(6)$, as well as the hormones human placental lactogen (hPL, chorionic somatomammotropin) (7) and chorionic gonadotropin (hCG) (7, $8)$. Since these proteins are not normally present in serum of men or nonpregnant women $(6-8)$, their appearance may provide a specific marker for neoplasm.

It has been demonstrated that hCG and the other human glycoprotein trophic hormones, thyroid-stimulating hormone (hTSH), luteinizing hormone (hLH), and follicle-stimulating hormone ( $\mathrm{hFSH}$ ), are composed of two nonidentical alpha and beta subunits (9-12). The alpha subunit is virtually identical among the four hormones while the beta subunit is unique and responsible for biologic specificity (11). Although early studies indicated that the hCG subunits (hCG- $\alpha, \mathrm{hCG}-\boldsymbol{\beta}$ ) might have intrinsic biologic activity $(10,11)$, more recent studies have demonstrated that the free subunits have little or no activity (13).

We have recently reported a case of bronchogenic carcinoma associated with ectopic production of biologically active hCG in vivo and in vitro (14). In addition to synthesizing complete hCG molecules, three clonal strains derived from the tumor also produced much larger amounts of either hCG- $\boldsymbol{\alpha}$ or $\mathrm{hCG}-\boldsymbol{\beta}$, and the ratio of the two subunits produced varied greatly among the clones (15). We now describe a patient with pancreatic carcinoma whose serum and tumor contained hCG- $\beta$ without accompanying hCG- $\alpha$ or complete hCG. The present case probably represents the first demonstration

${ }^{1}$ Abbreviations used in this paper: $\mathrm{B}$, bound; $\mathrm{hCG}$, human chorionic gonadotropin; hCG- $\alpha$, hCG alpha subunit; $\mathrm{hCG}-\boldsymbol{\beta}$, hCG beta subunit; hFSH, human follicle-stimulating hormone; hLH, human luteinizing hormone; hTSH, human thyroid-stimulating hormone; hPL, human placental lactogen; Kav, partition coefficient; PAP, placental alkaline phosphatase ; $\mathrm{T}$, total. 
of isolated polypeptide subunit production of ectopic origin.

\section{METHODS}

The paticnt. A 75-yr-old man (J. O.) was admitted to the Washington, D. C., Veteran's Administration Hospital with rectal bleeding of 1 wk duration. $10 \mathrm{yr}$ previously he had undergone a partial gastrectomy for duodenal ulcer, and in the past year he had noted intermittent abdominal pain without nausea, anorexia, or weight loss. Physical examination revealed left cervical and supraclavicular lymphadenopathy and a poorly defined central abdominal mass. There was no jaundice or gynecomastia. A cervical lymph node biopsy demonstrated a mixed carcinoma with adenomatous, squamous, undifferentiated, and giant cell elements. However, a variety of radiographic and other studies failed to elucidate the origin of the carcinoma or the source of the gastrointestinal bleeding. The patient was treated empirically with nitrogen mustard and methotrexate but expired 2 wk later. Postmortem examination revealed a tumor originating in the tail of the pancreas, metastatic to the liver, spleen, left adrenal, and various lymph nodes. There was no evidence of testicular or extragonadal choriocarcinoma. Microscopic examination of the pancreatic tumor, reviewed by the NIH Clinical Center Department of Pathologic Anatomy, showed a mixed adenosquamous carcinoma similar to that previously noted in the cervical lymph node. A serum sample obtained before chemotherapy and post-

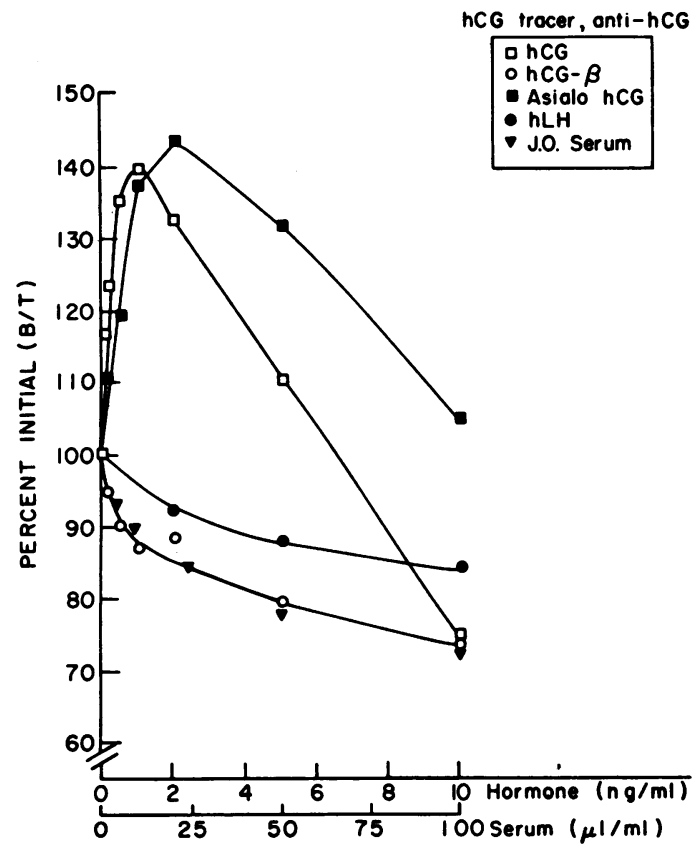

Figure 1 Reaction of hormones, subunits, and J. O. serum in a radioimmunoassay employing hCG tracer and antibody to hCG. This assay displayed paradoxical enhanced tracer binding specific for small increments of hCG or asialo-hCG, an effect apparently resulting from positive cooperativity between the two combining sites of a small population of antibodies (18). J. O. serum produced a displacement of the tracer from its antiboly similar to the effects of hCG- $\beta$ or hLH, but produced no enhanced binding effects.

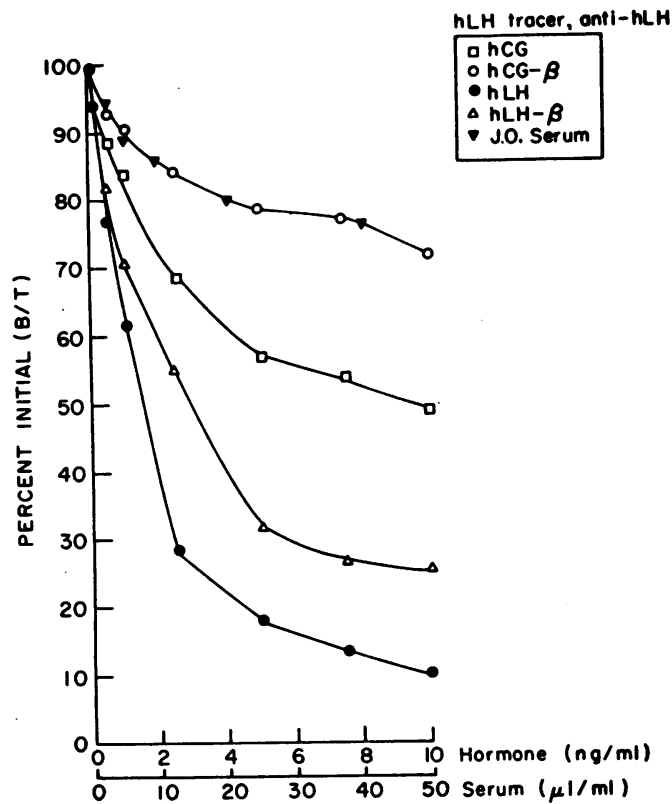

FigURE 2 Reaction of hormones, subunits, and J. O. serum in a radioimmunoassay employing $\mathrm{hLH}$ tracer and antibody to hLH. J. O. serum showed a response indistinguishable from that of $\mathrm{hCG}-\beta$, but different from that of hCG, hLH, or hLH- $\beta$-whether the data were analyzed arithmetically or by logit transformation (23).

mort.m tumor samples were stored at $-20^{\circ} \mathrm{C}$ for subsequent analysis.

Tumor extraction. Frozen tumor was lyophilized and ground into a fine powder in a laboratory mill (Wiley type, 40-mesh screen). The powder was glass-homogenized in cold $0.05 \mathrm{M}$ sodium phosphate $\mathrm{pH} 7.4(0.1 \% \mathrm{wt} / \mathrm{vol})$, the solution was centrifuged at $1500 \mathrm{~g}$ for $30 \mathrm{~min}$, and the supernate was saved for assay. These mild conditions were chosen to avoid perturbation of tumor polypeptides, and no attempt was made to achieve quantitative extraction.

Radioimmunoassays of hormones and subunits. Purified urinary hCG (ca. 10,000 IU/mg, bioassay) and asialo-hCG were provided by Dr. J. Hickman (16). hCG- $\alpha$ and hCG- $\beta$ purified after dissociation of urinary hCG in $8 \mathrm{M}$ urea were provided by Doctors R. Canfield and F. Morgan (10) as well as Dr. O. Bahl (9). Purified hLH, hFSH, hTSH, and hPL were supplied by the National Institute of Arthritis, Metabolism, and Digestive Diseases as were antisera to $\mathrm{hFSH}$ and hTSH. Antibodies to hCG, hCG- $\alpha$, hCG- $\beta, h L H$, and hPL were induced in guinea pigs or rabbits by multiple subcutaneous injections of purified hormone or subunit $(0.01-0.1 \mathrm{mg})$ dissolved in $0.05 \mathrm{M}$ sodium phosphate $\mathrm{pH} 7.4$ and complete Freund's adjuvant (50\% $\mathrm{vol} / \mathrm{vol}$ ). Antibodies to guinea pig or rabbit gamma globulin were induced in sheep by multiple intramuscular injections of gamma globulin (40-100 $\mathrm{mg}$, Cohn fraction II, Hyland Div., Travenol Laboratories, Inc., Costa Mesa, Calif.) dissolved similarly.

Hormones and subunits were iodinated with carrier-free ${ }^{125} \mathrm{I}$ to specific activities $50-100 \mu \mathrm{Ci} / \mu \mathrm{g}$ by the chloramine $T$ method (17). The iodinated proteins were separated from aggregated products of iodination and unreacted ${ }^{120} \mathrm{I}$ by chromatography on a $1.5 \times 80 \mathrm{~cm}$ column of beaded 
dextran gel (Sephadex G-100). Specific activities of labeled proteins were estimated from the percentage of radioactivity incorporated into the organic peaks of the chromatogram.

The radioimmunoassays of hCG (18), hPL (7), hFSH (19), and hTSH (20) were performed by our previously published methods, while the assay for $\mathrm{hLH}$ was a modification of our method (19), using purified hLH standards and anti-hLH rather than anti-hCG. The assays of hCG- $\alpha$ and $\mathrm{hCG}-\beta$ were performed with the respective labeled subunit and antibody to that subunit, a modification of the methods of Vaitukaitis and co-workers (21). In general, samples $(0.001-0.1 \mathrm{ml})$ of serum, tumor extract, chromatography fractions, or standards were assayed in duplicate 1 -ml incubates containing labeled hormone or subunit $(0.01-$ $0.1 \mathrm{ng}$ ), rabbit or guinea pig antibodies to the same hormone or subunit, human serum albumin $(0.1 \%$ [wt/vol], Pentex), and $1 \%$ (vol/vol) nonimmune rabbit or guinea pig serum (Pentex) diluted in $0.05 \mathrm{M}$ sodium phosphate pH 7.4. Hypopituitary plasma was added to certain tubes containing standards or $\mathrm{J}$. $\mathrm{O}$. serum in order to equalize the total volume $(0.1 \mathrm{ml})$ of serum and/or plasma in the incubates. Samples were incubated $3-5$ days at $4^{\circ} \mathrm{C}$ after which an appropriate amount of anti-gamma globulin was added to precipitate antibody-bound (B) radioactivity. After an additional $20-30 \mathrm{~h}$ incubation at $4^{\circ} \mathrm{C}$ the samples were centrifuged, the supernate decanted, and the drained precipitates counted in an automatic well-type gamma spectrometer. In control tubes without antibody, less than $2 \%$

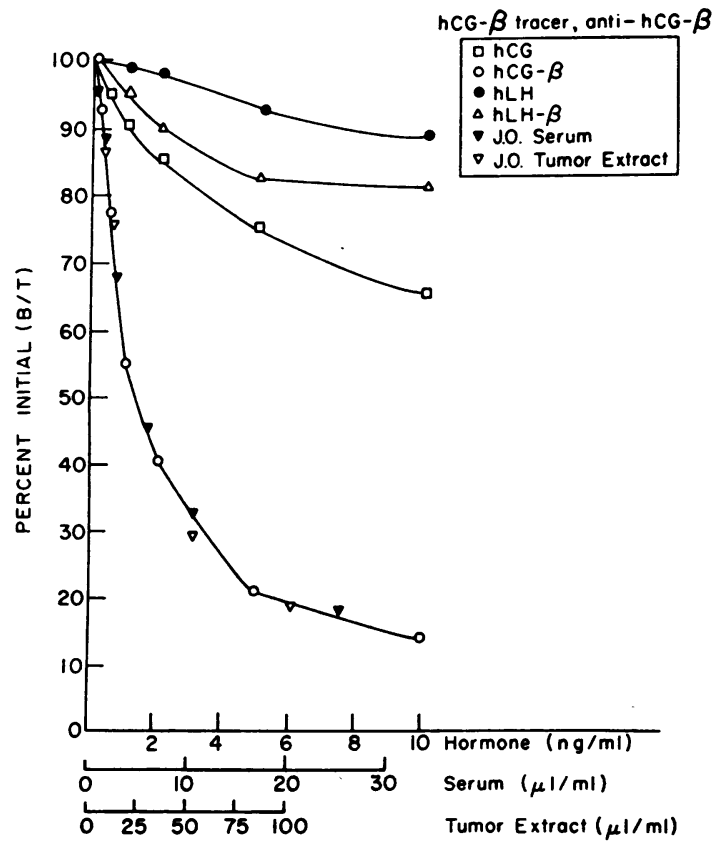

FIGURE 3 Reaction of hormones, subunits, J. O. serum, and tumor extract $(0.1 \%$ [wt/vol], see Methods $)$ in a radioimmunoassay employing hCG- $\beta$ tracer and antibody to hCG- $\beta$. J. O. serum and tumor extract showed a response indistinguishable from that of $\mathrm{hCG}_{-} \beta$ but different from $h C G, h L H$, or hLH- $\beta$ (analysis described in legend to Fig. 2). hCG- $\alpha$, hTSH, and hFSH produced no significant cross-reaction in this assay, at concentrations up to $100 \mathrm{ng} / \mathrm{ml}$.
TABLE I

Immunoassay of Placental Proteins in J. O. Serum and Tumor

\begin{tabular}{llll}
\hline & Protein & $\begin{array}{c}\text { Concen- } \\
\text { tration }\end{array}$ & $\begin{array}{c}\text { Normal value* } \\
\text { (reference) }\end{array}$ \\
\hline \multirow{3}{*}{ Serum } & & $n g / m l$ & \\
& hCG- $\beta$ & 300 & $<1(8)$ \\
& hCG- $\alpha$ & $<1$ & $<1 \ddagger$ \\
& hCG & $<6 \S$ & $<1(8)$ \\
& hPL & $<1$ & $<1(7)$ \\
& PAP & $<5 \|$ & $<5 \|(37)$ \\
Tumor extract 9 & & & \\
& hCG- $\beta$ & 60 & \\
& hCG- $\alpha$ & $<1$ & \\
& hCG & $<1$ & \\
\hline
\end{tabular}

* These proteins are not normally detected in males or nonpregnant females. The values represent the sensitivity limits of the assays.

$\ddagger$ Rosen and Weintraub, unpublished. Assay does not distinguish hCG- $\alpha$ from alpha subunits of hLH, hFSH, hTSH.

$\S$ Represents the sensitivity of this assay (18) in the presence

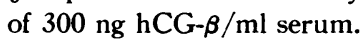

\| Assay performed by Dr. H. Sussman (37). This value is based on a specific activity of $400 \mu \mathrm{M}$ of paranitrophenyl phosphate hydrolysed per mg enzyme protein at $\mathrm{pH} 11.5$ and $37^{\circ} \mathrm{C}(38)$.

T Dry powder extracted $(0.1 \% \mathrm{wt} / \mathrm{vol})$ in $0.05 \mathrm{M}$ sodium phosphate $\mathrm{pH}$ 7.4.

of the radioactivity was precipitated and this blank was subtracted from all measurements. In the presence of excess antibody $70-95 \%$ of the tracer was precipitated, and this defined the total immunoreactive radioactivity $(\mathrm{T})$. The initial $\mathrm{B} / \mathrm{T}$ in the absence of unlabeled hormone or subunit was usually $0.4-0.6$, and the immunoassay data were normalized and represented as percent of initial (B/T). The specificity of the assays for hCG, hLH, and hCG- $\beta$ is shown in Figs. 1-3, and the normal values for all assays are shown in Tables I and II.

Gel chromatography. $5 \mathrm{ml}$ of $\mathrm{J}$. O. serum and $1 \mathrm{ng}$ of lightly labeled [ $\left.{ }^{131} \mathrm{I}\right] \mathrm{hCG}-\beta(8 \mu \mathrm{Ci} / \mu \mathrm{g})$ were cochromatographed on a $1.6 \times 89 \mathrm{~cm}$ column of Sephadex G-100. The column was equilibrated at $4^{\circ} \mathrm{C}$ and eluted with $0.15 \mathrm{M}$ sodium chloride, $0.01 \mathrm{M}$ sodium phosphate ( $\mathrm{pH} 7.4)$ with a hydrostatic pressure of $15 \mathrm{~cm}$ and a flow rate of $3 \mathrm{ml} / \mathrm{h}$. $1-\mathrm{ml}$ fractions were counted and assayed in hCG- $\beta, \mathrm{hCG}-\alpha$, and hCG radioimmunoassays; the small amount of ${ }^{181} \mathrm{I}$ radioactivity had a negligible effect in the ${ }^{125} \mathrm{I}$ channel used for immunoassay. The column was marked (Fig. 4) in separate experiments by determining the elution peaks of labeled bovine thyroglobulin (to determine void volume, Vo), hCG, asialo-hCG, and hLH, and the total column volume $(180 \mathrm{ml})$ was calculated from its dimensions. In another experiment it was determined that labeled and unlabeled (measured by immunoassay) hCG- $\beta$ had identical elution peaks on Sephadex G-100, with a partition coefficient (Kav) of 0.27 . This agrees with the Kav of 0.25 reported by Morgan and Canfield who measured the elu- 
TABLE II

Immunoassay of Hormones in J. O. Serum

\begin{tabular}{lccc}
\hline \multicolumn{1}{c}{ Hormone } & Concentration & \multicolumn{2}{c}{$\begin{array}{c}\text { Normal male range } \\
\text { (reference) }\end{array}$} \\
\hline $\mathrm{hTSH}$ & $5 \mu \mathrm{U}^{*} / \mathrm{ml}$ & $<1-6$ & $(20)$ \\
$\mathrm{hFSH}$ & $<1 \mathrm{mU} / \mathrm{ml}$ & $<1-10 \quad(19)$ \\
$\mathrm{hLH}$ & $\$$ & & \\
Estradiol & $<10 \mathrm{pg} / \mathrm{ml} \|$ & $14-70 \quad(39)$ \\
Testosterone & $130 \mathrm{ng} / 100 \mathrm{ml} \|$ & $450-1,100(40)$ \\
\hline
\end{tabular}

* Research standard B, Medical Research Council, Mill Hill, England.

$\ddagger$ Equivalent to $<2.5 \mu \mathrm{g} / 100 \mathrm{ml}$ of impure human pituitary gonadotropin reference standard LER 907 (19).

$\S$ This hormone could not be accurately measured because of interference from the hCG- $\beta$ (Fig. 2).

\| Performed by Hazleton Laboratories, Vienna, Va., using the methods of Loriaux et al. (39) and Dufau et al. (40).

tion peak of the subunit on G-100 by its absorbance at $280 \mathrm{~nm}(10)$

Gonadotropin bioassay. Gonadotropic activity of undiluted J. O. serum and tumor extract was measured by a modification of the mouse uterine weight bioassay (22).

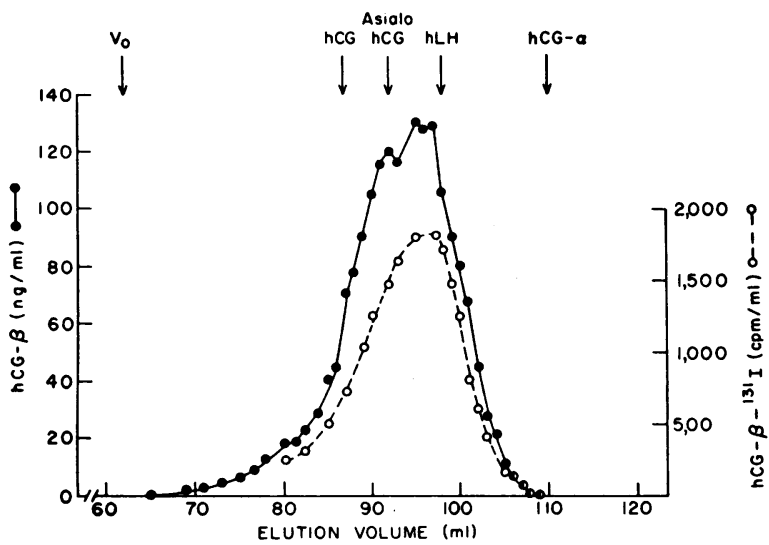

FIGURE 4 Gel chromatography of $\left[{ }^{131} \mathrm{I}\right]$ hCG- $\beta$ ( $1 \mathrm{ng}, 8$ $\mu \mathrm{Ci} / \mu \mathrm{g})$ added to J. O. serum $(5 \mathrm{ml})$. The Sephadex G-100 column $(1.6 \times 89 \mathrm{~cm}$, total volume $180 \mathrm{ml})$ was equilibrated at $4^{\circ} \mathrm{C}$ and eluted with $0.15 \mathrm{M}$ sodium chloride, $0.01 \mathrm{~m}$ sodium phosphate, $\mathrm{pH} 7.4$, with a hydrostatic pressure of $15 \mathrm{~cm}$ and a flow rate of $3 \mathrm{ml} / \mathrm{h}$. 1-ml fractions were counted for ${ }^{131} \mathrm{I}$ radioactivity (dashed line) and measured in an ${ }^{125} \mathrm{I}$ radioimmunoassay for $\mathrm{hCG}-\boldsymbol{\beta}$ (solid line, see Fig. 3). The elution peaks of various other hormones and subunits are indicated at the top of the figure; the alpha and beta subunits of hLH, hTSH, and hFSH were not chromatographed on this column, but would be expected to elute in the region of hCG- $\alpha$ (10-12). There appeared to be heterogeneity of the serum hCG- $\beta$ immunoactivity, including one component which coeluted with the beta tracer and another component with a lower elution volume. However, all parts of the chromatogram showed immunologic behavior indistinguishable from hCG- $\beta$ (see text).

3138 B. D. Weintraub and S. W. Rosen
TABLE III

Gonadotropin Bioassay of J. O. Serum and Tumor

\begin{tabular}{|c|c|c|c|}
\hline $\begin{array}{c}\text { Experi- } \\
\text { ment }\end{array}$ & Sample* & $\begin{array}{c}\text { Uterine } \\
\text { wt } \ddagger\end{array}$ & $P \S$ \\
\hline A & $\begin{array}{l}\text { Control plasma } \\
\text { +hCG\|(10 ng) } \\
\text { +hCG }(15 \mathrm{ng}) \\
\text { +hCG }(30 \mathrm{ng}) \\
\text { +hCG- } \beta \text { I }(1,000 \mathrm{ng}) \\
\text { +hCG- } \beta(1,000 \mathrm{ng})+\mathrm{hCG}(15 \mathrm{ng}) \\
\text { +hCG- } \beta(1,000 \mathrm{ng})+\mathrm{hCG}(30 \mathrm{ng}) \\
\text { J. O. serum** }\end{array}$ & \begin{aligned} \multicolumn{1}{c}{$m g$} \\
$9.8 \pm 0.5 \\
11.5 \pm 0.6 \\
18.8 \pm 0.5 \\
20.8 \pm 1.1 \\
9.0 \pm 0.4 \\
21.3 \pm 1.0 \\
22.5 \pm 1.3 \\
10.0 \pm 0.4\end{aligned}$ & $\begin{array}{c}0.1>P>0.05 \\
<0.001 \\
<0.001 \\
\text { NS\$ } \\
<0.001 \\
<0.001 \\
\text { NS\& }\end{array}$ \\
\hline B & $\begin{array}{l}\text { Control phosphate buffer } \\
\text { +hCG(15 ng) } \\
\text { J. O. tumor extract } \ddagger \\
\text { +hCG }(15 \mathrm{ng})\end{array}$ & $\begin{array}{r}9.0 \pm 0.4 \\
27.3 \pm 1.3 \\
10.5 \pm 1.0 \\
29.8 \pm 1.0\end{array}$ & $\begin{array}{c}<0.001 \\
\text { NS\$ } \\
<0.001\end{array}$ \\
\hline
\end{tabular}

* Samples $(0.5 \mathrm{ml})$ were injected $\mathrm{SC}$ daily for 3 days into four immature mice. Animals were killed $72 \mathrm{~h}$ after the first injection, and their uteri were dissected, blotted dry, and weighed.

$\ddagger$ Mean \pm SEM.

$\$ t$ test relative to control in that experiment. NS (not significant) indicates $P>0.1$.

|| Prepared by Dr. J. Hickman. Biologic activity ca. 10,000 IU/mg

II Prepared by Dr. O. Bahl.

** Containing $450 \mathrm{ng}$ hCG- $\beta$ by radioimmunoassay.

$\$ 0.15 \%$ (wt/vol) containing $90 \mathrm{ng}$ hCG- $\beta$ by radioimmunoassay.

Purified hCG or hCG- $\beta$ (Bahl) standards were diluted in $0.05 \mathrm{M}$ sodium phosphate $\mathrm{pH} 7.4$ containing $0.1 \%$ (wt/vol) human serum albumin, and were added either to control hypopituitary plasma, sodium phosphate buffer, or J. O. tumor extract (Table III). $0.5 \mathrm{ml}$ of each sample was injected subcutaneously daily for 3 days into four immature Swiss albino mice (8-10 g, Institute of Cancer Research, Philadelphia, $\mathrm{Pa}$.). The animals were killed $72 \mathrm{~h}$ after the first injection, and their uteri were dissected, nicked to allow fluids to escape, blotted dry, and weighed on a torsion balance. The response of treated groups versus the control in that experiment was analyzed by unpaired $t$ test, after a preliminary $F$ test indicated equal variance between the treated and control groups in each experiment.

\section{RESULTS}

Immunoassays for placental proteins. Although this patient had no clinical features suggesting ectopic hormone production, his serum and tumor were examined as part of a prospective study to determine the incidence and specificity of ectopic placental proteins as cancer markers." Neither placental lactogen nor placental alkaline phosphatase was detected in the serum (Table I), but an immunoreactive material was noted in the hCG radioimmunoassay (Fig. 1). This substance produced a weak displacement of the hCG tracer from its antibody similar to the effects of hCG- $\beta$ or hLH but did not produce enhanced binding effects characteristic of hCG or asialo-hCG in this assay (18). Examination of the serum in an assay for $\mathrm{hLH}$ revealed that the material was again

${ }^{2}$ Rosen, S. W., F. M. Muggia, B. D. Weintraub, and H. H. Hansen. Manuscript in preparation. 
similar to $h C G-\beta$ and different from $h C G, h L H$, or hLH- $\beta$ (Fig. 2). Finally, examination of serum and tumor extract in an assay for hCG- $\beta$ again showed that they contained material immunologically indistinguishable from hCG- $\beta$ (Fig. 3). The serum and tumor immunoreactivity behaved parallel to hCG- $\beta$ and different from other cross-reacting hormones and subunits, whether the dose-response curves were analyzed arithmetically or by logit transformation (23). There appeared to be a quantitative discrepancy among the three assays: the J. O. serum concentration read against hCG- $\beta$ standards, was $100 \mathrm{ng} / \mathrm{ml}$ in the hCG assay, $200 \mathrm{ng} / \mathrm{ml}$ in the $\mathrm{hLH}$ assay, and $300 \mathrm{ng} / \mathrm{ml}$ in the hCG- $\beta$ assay. However, the significance of these differences is not clear, particularly in view of the inaccuracy of quantification with the shallow hCG- $\beta$ response curves in the hCG and hLH assays.

Despite the presence of hCG- $\beta$ in serum $(300 \mathrm{ng} / \mathrm{ml})$ and tumor extract $(60 \mathrm{ng} / \mathrm{ml}), \mathrm{hCG}-\alpha$ was not detected $(<1 \mathrm{ng} / \mathrm{ml}$ ) in these specimens (Table I). Nor could any enhanced binding effects characteristic of hCG be elicited in multiple dilutions of these samples (Fig. 1). An absence of these effects would normally indicate $<1$ ng $\mathrm{hCG} / \mathrm{ml}$ serum ( $<0.1 \mathrm{ng}$ hCG per $\mathrm{ml}$ assay tube), but other experiments indicated that the presence of greater than a 50 -fold excess of hCG- $\beta$ significantly diminished the enhanced binding effects of hCG. Thus the absence of enhanced binding effects in various dilutions of serum that contained $300 \mathrm{ng}$ hCG $-\beta / \mathrm{ml}$ indicated that the hCG concentration was $<6 \mathrm{ng} / \mathrm{ml}$. The absence of hCG was also supported by the gel chromatography and bioassay studies (see below).

Other endocrine data. The serum concentration of hTSH was normal (Table II) in an assay that showed no cross-reaction with hCG- $\beta$, and its presence suggested the normal biosynthesis of at least one complete glycoprotein hormone of nonneoplastic origin. $\mathrm{hFSH}$ was not detected, but this radioimmunoassay does not always distinguish normal from low values (19). hLH could not be accurately measured because of significant crossreaction of high concentrations of hCG- $\beta$ in this assay (Fig. 2). Thus it was not possible to determine if pituitary gonadotropin synthesis was normal. Of additional interest was the fact that serum estradiol was not detected $(<10 \mathrm{pg} / \mathrm{ml}$ ), in contrast to the elevated concentration and production rates of estrogens reported in men with both trophoblastic (24) and nontrophoblastic (7) tumors secreting hCG. Serum testosterone was also low, although this hormone is usually normal in men with hCG-secreting tumors (24).

Gel chromatography. The immunoreactive material in serum and tumor extract had an elution volume similar to that of $\left.{ }^{181} I\right]$ hCG- $\beta$ on Sephadex G-100 (Fig. 4) but different from hCG, hCG- $\alpha$, and the subunits of other glycoprotein hormones (10-12). There appeared to be some heterogeneity of this material, including a component apparently more excluded from the gel than the hCG- $\beta$ tracer, noted in three chromatography experiments of serum and one of tumor extract. However, multiple components have not yet been resolved, and all parts of the chromatogram showed immunologic behavior parallel to that of hCG- $\beta$. Appropriate fractions of the chromatogram were examined in the hCG- $\alpha$ immunoassay (tubes 105-115) and in the hCG assay (tubes 85-93), and neither of these proteins was detected ( $<1 \mathrm{ng} / \mathrm{ml}$ fraction).

Bioassay. Serum and tumor extract $(1.5 \mathrm{ml})$ containing 450 and $90 \mathrm{ng}$ of hCG- $\beta$, respectively, were found to have no gonadotropic activity in the mouse uterine bioassay (Table III). This assay was regularly sensitive to $10-15 \mathrm{ng}(0.10-0.15 \mathrm{IU})$ of $\mathrm{hCG}$ but showed no response to $1,000 \mathrm{ng}$ of hCG- $\beta$ (Bahl). Moreover the presence of excess hCG- $\beta$ did not inhibit the response to even small amounts of standard hCG. These results agree with those of Rayford and coworkers who found that the apparent biologic activity of certain preparations of hCG- $\beta$ could be fully accounted for by $1-5 \%$ contamination with hCG (13). Small amounts of standard hCG added to the tumor extract showed full biologic activity, indicating that there were no significant degradative enzymes or other inhibitors of biologic activity. A similar recovery experiment could not be performed with the limited supply of J. O. serum, but we have not encountered significant inhibitors of gonadotropin activity in a variety of sera tested in this assay.

\section{DISCUSSION}

The material identified in this patient's serum and pancreatic tumor was quite similar to standard hCG- $\beta$ in its immunologic, biologic, and physicochemical properties. In three different radioimmunoassays, displaying markedly different reactions with glycoprotein hormones and their subunits, the substance was indistinguishable from hCG- $\beta$. The complete absence of gonadotropic bioactivity in serum and tumor was also consistent with the presence of isolated hCG- $\boldsymbol{\beta}$. In gel chromatography the betalike substance had an elution volume similar to that of standard hCG- $\beta$ but different from hCG- $\alpha$ and from the alpha and beta subunits of other glycoprotein trophic hormones. The characteristically low elution volume of hCG- $\beta$ in gel chromatography is only partially explained by its higher molecular weight and may also be attributable to its uniquely high sialic acid content $(9,10)$.

Three gel chromatography experiments suggested that the hCG- $\beta$ in J. O. serum might be heterogeneous, including a component with an elution volume slightly lower than the marker $\left.{ }^{191} \mathrm{I}\right]$ hCG- $\beta$. However, multiple components were never clearly resolved by gel chroma- 
tography, and this question is currently being investigated by other physicochemical methods. It is relevant that Hammond and coworkers have reported heterogeneity of complete hCG produced by clonal lines of choriocarcinoma in vitro, including at least two components separated by isoelectric focusing differing primarily in sialic acid content (25). Although heterogeneity in gel chromatography is usually attributed to species of significantly different molecular weight, it may also be due to differences in sialic acid content, as shown by the different elution volumes of standard and asialo-hCG (Fig. 4). This difference in elution volume is probably more than can be accounted for by a difference in molecular weight of 3,000 and probably reflects conformational changes (26). Furthermore, urinary hCG may contain less sialic acid than the serum or placental hormone (27), and it is possible that hCG- $\beta$ prepared from the latter sources might display heterogeneity or have slightly different properties than the urinary hCG- $\beta$ used âs a column marker in these experiments.

The most direct proof of ectopic polypeptide production is the demonstration of an arteriovenous gradient across the tumor bed or in vitro production of polypeptide by tumor. Although these criteria were not demonstrated in this case, it is highly likely that the pancreatic tumor was synthesizing hCG- $\beta$. Extracts of tumor showed material indistinguishable from that present in the serum. Furthermore, in men there are no other known nonneoplastic sources of hCG- $\beta$ that could account for detectable serum concentrations or could be the source of material "trapped" by tumor. Braunstein and coworkers examined 443 patients with nonneoplastic diseases in a radioimmunoassay that measured both hCG and hCG- $\beta$ ( 8 ). In these controls they detected neither of these antigens except in sera from three female blood bank donors in whom the possibility of pregnancy was not eliminated. In our smaller control series of $40 \mathrm{pa}$ tients (Weintraub and Rosen, unpublished) there have likewise been no sera with detectable $\mathrm{hCG}-\beta$, and it thus appears that this subunit may be another specific tumor marker in males or nonpregnant females.

Despite the presence of $\mathrm{hCG}-\boldsymbol{\beta}$ in serum and tumor there was no evidence of hCG- $\alpha$ or complete hCG in these specimens. The radioimmunoassay for hCG- $\alpha$ would have detected a serum concentration as little as $0.5 \%$ that of the beta subunit, while the immunoand bioassays of hCG would have detected as little as $2 \%$. The absence of $\mathrm{hCG}$ in the serum is particularly significant since its metabolic clearance rate is much slower than that of hCG- $\beta$ in the rat (28). If these clearance differences apply to man, then any secretion of hCG by the tumor would lead to a disproportionately higher serum concentration. Further, the absence of gynecomastia and the low serum estradiol concentration are consistent with the absence of hCG in serum. In fact, the low concentrations of serum estradiol, testosterone, and hFSH raise the possibility of associated pituitary gonadotropin deficiency of unknown origin.

The isolated subunit production demonstrated in this case provides an in vivo counterpart to our previous in vitro studies showing unbalanced production of hCG- $\alpha$ and $\mathrm{hCG}-\boldsymbol{\beta}$ in three clonal strains derived from a bronchogenic carcinoma (15). Although each of these clones synthesized small quantities of hCG, each secreted much greater amounts of one or both subunits, and the ratio of alpha and beta production varied greatly among the clones. Neither that study nor the present one clarifies the mechanism of ectopic polypeptide production, although the data are consistent with the widely held "derepression" theory which proposes that malignancy results in a transcription of previously repressed DNA (2-4). According to this theory, isolated production of only one subunit would imply that $\mathrm{hCG}-\alpha$ and hCG- $\boldsymbol{\beta}$ are independently transcribed. Unfortunately little is known about the mechanism of normal hCG- $\alpha$ and $\mathrm{hCG}-\boldsymbol{\beta}$ subunit production and their assembly to form complete hCG. The simple derepression model also predicts that the ectopic hCG- $\beta$ should have the same structure and properties as normal $\mathrm{hCG}-\boldsymbol{\beta}$, including the ability to combine with hCG- $\alpha$ to form biologically active hCG (11). However, we have not yet purified enough of the ectopic hCG- $\beta$ to perform chemical analysis or combination experiments.

Isolated and unbalanced production of hCG subunits is somewhat analogous to unbalanced production of heavy and light immunoglobulin chains by certain human and mouse lymphoid-plasma cell neoplasms (29-31). However the latter tumors are presumably derived from cells normally engaged in the production of immunoglobulins and do not represent ectopic subunit syndromes. For various antibody-producing cells it has been shown that the synthesis of heavy and light immunoglobulin chains is independently controlled, including translation on separate polyribosomes $(31,32)$. The two chains are then linked by disulfide bonds and noncovalent forces in contrast to the solely noncovalent forces that bind the subunits of the glycoprotein hormones (11). Further study will be necessary to determine whether the mechanism of unbalanced hCG subunit synthesis is similar to that of unbalanced immunoglobulin chain synthesis.

It is probable that other instances of ectopic subunits will soon be recognized. Braunstein and co-workers found hCG-like material in over $7 \%$ of a large number cancer sera, and in some instances they were not able to exclude the possibility that hCG- $\beta$ was being measured (8). Recent data from Franchimont et al. (33) and from our laboratory (34) indicate that the alpha subunit of 
the glycoprotein hormones may be found in higher than normal concentrations in the sera of certain cancer patients, and we have studied one such patient with an alpha serum concentration of $20,000 \mathrm{ng} / \mathrm{ml}$ (34). Unlike $\mathrm{hCG}-\beta$, the common alpha subunit as well as the beta subunits of hLH, hFSH, and hTSH are not specific cancer markers since they are components of normally circulating hormones and may be secreted from the pituitary or derive from peripheral metabolism of the hormone $(35,36)$. Even if they are not specific for cancer their quantitation in serum may prove helpful in the diagnosis and management of neoplasm. Further study of ectopic subunit production may also yield insight into the events of both normal and neoplastic protein synthesis.

\section{ACKNOWLEDGMENTS}

The authors are grateful to Doctors Franco Muggia and Heine Hansen for obtaining serum and tumor samples and to Ida Stotler and J. Andrew McCammon for technical assistance. We also appreciate the various reagents provided by Drs. Robert Canfield, Om Bahl, Jean Hickman, and the Hormone Distribution Program of the National Institute of Arthritis, Metabolism, and Digestive Diseases.

Part of this investigation was performed while Dr. Weintraub was a member of the Department of Medicine, Massachusetts General Hospital, Boston, Mass., supported by research grants from the U. S. Public Health Service (CA 12749 and AM 15135).

\section{REFERENCES}

1. Bower, B. F., and G. S. Gordan. 1965. Hormonal effects of nonendocrine tumors. Ann. Rev. Med. 16: 83.

2. Lipsett, M. B. 1965. Hormonal syndromes associated with cancer. Cancer Res. 25: 1068.

3. Liddle, G. W., W. E. Nicholson, D. P. Island, D. N. Orth, K. Abe, and S. C. Lowder. 1969. Clinical and laboratory studies of ectopic humoral syndromes. $R e-$ cent Prog. Horm. Res. 25 : 283.

4. Weintraub, B. D., and S. W. Rosen. 1973. Competitive radioassays and "specific" tumor markers. Metab. (Clin. Exp.). 22: 1119.

5. Rosen, S. W., C. E. Becker, S. Schlaff, J. Easton, and M. C. Gluck. 1968. Ectopic gonadotropin production before clinical recognition of bronchogenic carcinoma. N. Engl. J. Med. 279: 640.

6. Stolbach, L. L., M. J. Krant, and W. H. Fishman. 1969. Ectopic production of an alkaline phosphatase isoenzyme in patients with cancer. N. Engl. J. Med. $281: 757$.

7. Weintraub, B. D., and S. W. Rosen. 1971. Ectopic production of human chorionic somatomammotropin by nontrophoblastic cancers. J. Clin. Endocrinol. Metab. 32: 94.

8. Braunstein, G. D., J. L. Vaitukaitis, P. P. Carbone, and G. T. Ross. 1973. Ectopic production of human chorionic gonadotropin by neoplasms. Ann. Intern. Med. 78: 39.

9. Swaminathan, N., and O. P. Bahl. 1970. Dissociation and recombination of the subunits of human chorionic gonadotropin. Biochem. Biophys. Res. Commun. 40: 422.

10. Morgan, F. J., and R. E. Canfield. 1971. Nature of the subunits of human chorionic gonadotropin. Endocrinology. 88 : 1045.

11. Pierce, J. G. 1971. Eli Lilly Lecture: The subunits of pituitary thyrotropin-their relationship to other glycoprotein hormones. Endocrinology. 89: 1331.

12. Saxena, B. B., and P. Rathnam. 1971. Dissociating phenomenon and subunit nature of follicle-stimulating hormone from human pituitary glands. J. Biol. Chem. 246: 3549.

13. Rayford, P. L., J. L. Vaitukaitis, G. T. Ross, F. J. Morgan, and R. E. Canfield. 1972. Use of specific antisera to characterize biologic activity of HCG- $\beta$ subunit preparations. Endocrinology. 91: 144.

14. Rabson, A. S., S. W. Rosen, A. H. Tashjian, Jr., and B. D. Weintraub. 1973. Production of human chorionic gonadotropin in vitro by a cell line derived from a carcinoma of the lung. J. Natl. Cancer Inst. 50: 669.

15. Tashjian, A. H., Jr., B. D. Weintraub, N. J. Barowsky, A. S. Rabson, and S. W. Rosen. 1973. Subunits of human chorionic gonadotropin: unbalanced synthesis and secretion by clonal cell strains derived from a bronchogenic carcinoma. Proc. Natl. Acad. Sci. U. S. A. 70: 1419

16. Van Hall, E. V., J. L. Vaitukaitis, G. T. Ross, J. W. Hickman, and G. Ashwell. 1971. Immunological and biological activtiy of HCG following progressive desialylation. Endocrinology. 88: 456.

17. Hunter, W. M., and F. C. Greenwood. 1962. Preparation of iodine-131 labelled human growth hormone of high specific activity. Nature (Lond.). 194: 495.

18. Weintraub, B. D., S. W. Rosen, J. A. McCammon, and R. J. Perlman. 1973. Apparent cooperativity in radioimmunoassay of human chorionic gonadotropin. Endocrinology. 92 : 1250.

19. Rosen, S. W., and B. D. Weintraub. 1971. Monotropic increase of serum FSH correlated with low sperm count in young men with idiopathic oligospermia and aspermia. J. Clin. Endocrinol. Metab. 32: 410.

20. Bode, H. H., M. Danon, B. D. Weintraub, F. Maloof, and J. D. Crawford. 1973. Partial target organ resistance to thyroid hormone. J. Clin. Invest. 52: 776.

21. Vaitukaitis, J. L., G. D. Braunstein, and G. T. Ross. 1972. A radioimmunoassay which specifically measures human chorionic gonadotropin in the presence of human luteinizing hormone. Am. J. Obstet. Gynecol. 113: 751.

22. Klinefelter, H. F., Jr., F. Albright, and G. C. Griswold. 1943. Experience with quantitative test for normal or decreased amounts of follicle stimulating hormone in urine in endocrinological diagnosis. J. Clin. Endocrinol. Metab. 3: 529.

23. Rodbard, D., W. Bridson, and P. L. Rayford. 1969. Rapid calculation of radioimmunoassay results. J. Lab. Clin. Med. $74: 770$.

24. Kirschner, M. A., J. A. Wider, and G. T. Ross. 1970 Leydig cell function in men with gonadotrophin-producing testicular tumors. J. Clin. Endocrinol. Metab. 30: 504 .

25. Hammond, J. M., W. E. Bridson, P. O. Kohler, and A. Chrambach. 1971. Physical characteristics of immunoreactive chorionic gonadotropin produced in culture. Endocrinology. 89: 801.

26. Mori, K. F., and T. R. Hollands. 1971. Physicochemical characterization of native and asialo human chorionic gonadotropin. J. Biol. Chem. 246: 7223.

27. Dufau, M. L., T. Tsuruhara, and K. J. Catt. 1972. Interaction of glycoprotein hormones with agaroseconcanavalin A. Biochim. Biophys. Acta. 278: 281. 
28. Braunstein, G. D., J. L. Vaitukaitis, and G. T. Ross. 1972. The in vivo behavior of human chorionic gonadotropin after dissociation into subunits. Endocrinology. 91: 1030 .

29. Franklin, E. C., J. Lowenstein, B. Bigelow, and M. Meltzer. 1964. Heavy chain disease. A new disorder of serum $\gamma$-globulins : report of the first case. Am. J. Med. $37: 332$.

30. Salmon, S. E., and B. A. Smith. 1970. Immunoglobulin synthesis and total body tumor cell number in $\mathrm{IgG}$ multiple myeloma. J. Clin. Invest. 49: 1114.

31. Schubert, D., and M. Cohn. 1968. Immunoglobulin biosynthesis III. Blocks in defective synthesis. J. Mol. Biol. $38: 273$.

32. Namba, Y., and M. Hanaoka. 1969. Immunoglobulin synthesis by cultured mouse myeloma cells. J. Immunol. $102: 1486$

33. Franchimont, P., U. Gaspard, A. Reuter, and G. Heynen. 1972. Polymorphism of protein and polypeptide hormones. Clin. Endocrinol. 1: 315.

34. Weintraub, B. D., S. W. Rosen, A. S. Rabson, and A. H. Tashjian, Jr. 1973. Isolated and unbalanced production of alpha and beta HCG subunits: new ectopic syndromes. Clin. Res. 21: 506. (Abstr.)
35. Kourides, I. A., B. D. Weintraub, M. A. Levko, and F. Maloof. 1973. Purification of the beta subunit of human thyrotropin (HTSH- $\beta$ ) and development of a specific radioimmunoassay (RIA). Clin. Res. 21: 496. (Abstr.)

36. Rabinowitz, D., R. Benveniste, L. Frohman, J. Bell and I. Spitz. 1973. "Little" luteinizing hormone (LH): the appearance in serum of an hLH-related peptide, possibly a subunit, after LHRH stimulation. J. Clin. Invest. 52: 67a. (Abstr.)

37. Sussman, H. H., M. Bowman, and J. L. Lewis, Jr. 1968. Placental alkaline phosphatase in maternal serum during normal and abnormal pregnancy. Nature (Lond.). 218: 359 .

38. Sussman, H. H., P. A. Small, Jr., and E. Cotlove. 1968. Human alkaline phosphatase. Immunochemical identification of organ-specific isoenzymes. J. Biol. Chem. $243: 160$.

39. Loriaux, D. L., H. J. Ruder, and M. B. Lipsett. 1971. The measurement of estrone sulfate in plasma. Steroids. 18: 463.

40. Dufau, M. L., K. J. Catt, T. Tsuruhara, and D. Ryan. 1972. Radioimmunoassay of plasma testosterone. Clin. Chim. Acta. 37 : 109. 